\title{
sciendo
}

\section{EVALUATION OF GENETIC DAMAGE IN Oreochromis mossambicus EXPOSED TO SELECTED NANOPARTICLES BY USING MICRONUCLEUS AND COMET BIOASSAYS}

\section{Puthan Variyam Vidya, Kumari Chidambaran Chitra*}

Endocrinology and Toxicology Laboratory, Department of Zoology, University of Calicut, Malappuram District, Kerala, 673 635, India

*Corresponding Author, Email: kcchitra@yahoo.com

\section{ARTICLE INFO}

Received: 28 March 2018

Received in revised form: 21 May 2018

Accepted: 21 June 2018

Online first: 23 August 2018

\section{Keywords:}

Oreochromis mossambicus

Nanoparticles

Erythrocyte

Genotoxicity

Micronucleus test

Comet assay

\begin{abstract}
The purpose of the present study is to extend knowledge on the adverse effects of nanoparticles by evaluating genotoxicity as environmental risk assessment in Oreochromis mossambicus. Fish were exposed to sublethal concentrations of the selected nanoparticles, namely silicon dioxide $\left(\mathrm{SiO}_{2} \mathrm{NPs}-12 \mathrm{mg} / \mathrm{L}\right)$, aluminium oxide $\left(\mathrm{Al}_{2} \mathrm{O}_{3} \mathrm{NPs}-4 \mathrm{mg} / \mathrm{L}\right)$, titanium dioxide $\left(\mathrm{TiO}_{2} \mathrm{NPs}-16.4 \mathrm{mg} / \mathrm{L}\right)$ and iron oxide $\left(\mathrm{Fe}_{3} \mathrm{O}_{4} \mathrm{NPs}-15 \mathrm{mg} / \mathrm{L}\right)$ for short-term (24, 72 and $96 \mathrm{~h}$ ) and long-term durations (15, 30 and 60 days). Genetic damages such as cytoplasmic, nuclear and DNA damage were measured in the erythrocytes of fish by using standard genotoxicity tests such as micronucleus test and comet assay. The frequencies of micronuclei along with nuclear and cytoplasmic abnormalities were scored and compared with the control group. The intensity of micronuclei along with other nuclear and cytoplasmic anomalies are found to be increased significantly $(p<0.05)$ in time-dependent manner in all exposure groups when compared to the control group, thereby indicating chromosomal damage as a result of contact with nanoparticles. The tail length and percent of tail DNA within the comet significantly $(p<0.05)$ increased in time-dependant manner after exposure to all nanoparticles, demonstrating an increase in DNA damage. Taken together, by using micronucleus test and comet assay, it is evident that the selected nanoparticles at sublethal concentrations induced genetic damage in Oreochromis mossambicus.
\end{abstract}

Vidya, P.V., Chitra, K.C. (2018): Evaluation of genetic damage in Oreochromis mossambicus exposed to selected nanoparticles by using micronucleus and comet bioassays. Croatian Journal of Fisheries, 76, 115-124. DOI: 10.2478/ cjf-2018-0015.

\section{INTRODUCTION}

Aquatic ecosystem is formed by the interaction of both abiotic and biotic components. Among 2.5\% of freshwater on earth, only $0.014 \%$ is easily available as human resource in the form of soil moisture, water vapour, usable groundwater, flowing water such as lakes and streams. Unfortunately, freshwater ecosystems are unbalanced by several factors due to human 
activities, mainly by the exposure of pollutants like industrial, agriculture, urban waste, atomic waste, etc., which results in harmful or disastrous effects in aquatic organisms (Bickham et al., 2000). The intensity of adverse effects depends on the nature of pollutants released, concentration of pollutants, bioaccumulation and biomagnification properties, which would finally result in disruption of food chains, death of aquatic animals, diseases and finally imbalance of the ecosystems. Among all aquatic animals, the impact of pollutants on fish has received much attention over the past few decades, as fish occupies a direct link to human food chain.

There are several measures adopted in ecotoxicology to detect the problems affecting the health of fish. In the late 1970s, the relevance of detecting the genotoxic risks related to aquatic pollutants was of great importance. In genotoxicity, DNA lesions are effectively screened by employing several methods such as chromosomal aberration, sister chromatid test, comet assay, micronucleus test and other mutagenic and carcinogenic biomarkers. Micronucleus test and comet assay are cost-effective, sensitive and more reliable test systems widely used to assess the genotoxicity of any pollutants. The analysis of genotoxicity refers mainly to the responses in nucleic acids, either DNA or mRNA, that also damage the genome or causes some adaptive change in gene expression (Lam and Gray, 2003). The main reasons behind the biomonitoring of genotoxicity in aquatic organisms are: it has a protective role to avoid contamination-induced mutations that skew genetic diversity in natural population and also detect carcinogenicity or mutagenicity of pollutants in aquatic life which affect the health status and also prevent carcinogens to enter into humans through the food chain (De Flora et al., 1991). Therefore, the assessment of genetic damage in aquatic animals provides environmental biomonitoring for water pollution control.

Recently, the extensive use of nano-scale particles in various industrial, domestic and personal care products generate much alarm over the environmental impact on aquatic organisms, particularly on fish. Conceptually, there are debatable opinions regarding the chemistry, behaviour, biological uptake, body distribution, metabolism and excretion of nanoparticles in fish. There are several studies suggesting that the adverse effects of nanoparticles occur mainly due to the size, shape, agglomeration and other physico-chemical properties. Aluminium oxide nanoparticles $\left(\mathrm{Al}_{2} \mathrm{O}_{3}\right.$-NPs) are one among the most abundantly produced nanoparticles that have been widely used in diverse fields as chemosensors, biosensors, biofiltration, heat transfer fluids, adsorbent in analytical techniques, environmental remediation, abrasive for polishing optics and jewellery, catalyst in chemical reactions, waste water treatment, nanoenergetics, diesel fuel additive, etc. (Colvin, 2003). Recently, $\mathrm{Al}_{2} \mathrm{O}_{3} \mathrm{NPs}$ has been used as an effective bactericidal agent, meanwhile it also possesses neurodegenerative property affecting blood-brain barrier that results in endothelial toxicity such as loss of structure or function of neurons and death of neurons in organisms, including humans (Chen et al., 2008; Ansari et al., 2014). Iron oxide nanoparticles ( $\mathrm{Fe}_{3} \mathrm{O}_{4} \mathrm{NPs}$ ) are found naturally in the environment as particulate matter generated as emission from volcanic eruptions, having wide varieties of biological and medical applications including magnetic resonance imaging, purification of biological fluids, drug delivery, immunoassay, etc. (Gupta and Gupta, 2005).

Silicon dioxide nanoparticles $\left(\mathrm{SiO}_{2} \mathrm{NPs}\right)$ are extensively applied in biomedical and biotechnological applications such as gene and siRNA delivery, biosensors, nanomedicine and in cancer therapy (Li et al., 2012). Titanium dioxide nanoparticles $\left(\mathrm{TiO}_{2}-\mathrm{NPS}\right)$ have numerous industrial applications and are also widely used in consumer products such as water treatment agents, disinfectant sprays, selfcleaning surface coatings, sporting equipment, light-emitting diodes, sunscreens, solar cells and in cosmetics (Chen and Mao, 2007). In a toxicological point of view, the nano-scale size and surface are important properties of nanoparticles that allow a greater proportion of the atoms or molecules to display on its surface than within the particles. As a result, the nanoparticles become chemically and biologically reactive, thereby causing potential negative impact on organisms. Owing to a small size and wide surface area, nanoparticles have been able to penetrate through the biological barriers and move easily through the biological systems (Oberdorster et al., 2005). Nanotoxicological research has reported adverse toxic effects of nanoparticles such as disruption of cellular function (Sayes and Warheit, 2009), generation of reactive oxygen species (Vidya and Chitra, 2018a, 2018b), neurotoxicity and organ damage including significant lesions on the lung, liver and kidneys (De Jong and Borm, 2008; Sumi and Chitra, 2017), gill damage and associated respiratory problems (Federici et al., 2007), and DNA damage (Nel et al., 2006). Metal oxide nanoparticles have been shown to induce micronuclei and other nuclear anomalies in human peripheral blood lymphocyte culture and caused cytotoxicity in Chinese hamster ovary-K1 cells (Vidya et al., 2017; Vidya and Chitra, 2017a). The present study was designed to evaluate the genotoxic effects of the selected four metal oxide nanoparticles such as silicon dioxide $\left(\mathrm{SiO}_{2} \mathrm{NPs}\right)$, aluminium oxide $\left(\mathrm{Al}_{2} \mathrm{O}_{3} \mathrm{NPs}\right)$, titanium dioxide $\left(\mathrm{TiO}_{2} \mathrm{NPs}\right)$ and iron oxide $\left(\mathrm{Fe}_{3} \mathrm{O}_{4} \mathrm{NPs}\right)$ at sublethal concentrations in Oreochromis mossambicus by using micronucleus test and comet assay.

\section{MATERIALS AND METHODS}

\section{Maintenance of the test animal}

Oreochromis mossambicus $(6 \pm 1.5 \mathrm{~g} ; 6.5 \pm 1.0 \mathrm{~cm})$ were 
collected from a local fish farm, Safa Aquarium, Kozhikode, Kerala $\left(11^{\circ} 22^{\prime} \mathrm{N}, 75^{\circ} 85^{\prime} \mathrm{E}\right)$ and acclimatized to the laboratory conditions for two weeks prior to the experiment. Fish were maintained in glass tanks of $40 \mathrm{~L}$ capacity supplied with dechlorinated, well-aerated, closed-circuit water. The physico-chemical features of the tap water were estimated as per APHA guidelines (1998), maintaining water temperature $\left(28 \pm 2^{\circ} \mathrm{C}\right), \mathrm{pH}(6.5$ to 7.5$)$ and with continuous aeration so as to keep the oxygen saturation of water between 70 to $100 \%$, in both control and treatment groups.

\section{Test chemical}

$\mathrm{Al}_{2} \mathrm{O}_{3}$ NPs (Cat. No: 544833) and $\mathrm{SiO}_{2}$-NPs (Cat. No: 1940323) were obtained from SISCO Research Laboratory (SRL), India. $\mathrm{TiO}_{2} \mathrm{NPs}$ (Titanium (IV) oxide, mix of anatase and rutile, Cat. No. 634662) and $\mathrm{Fe}_{3} \mathrm{O}_{4}$-NPs (Cat. No. 637106) were obtained from Sigma Aldrich, Germany. The purity and size of the nanoparticles such as $\mathrm{Al}_{2} \mathrm{O}_{3} \mathrm{NPs}-16.7$ $\mathrm{nm}, \mathrm{Fe}_{3} \mathrm{O}_{4} \mathrm{NPs}-15.65 \mathrm{~nm}, \mathrm{SiO}_{2} \mathrm{NPs}-1 \mathrm{~nm}$ and $\mathrm{TiO}_{2} \mathrm{NPs}-11.4$ $\mathrm{nm}$ were confirmed by X-ray diffraction and Transmission Electron Microscopy using Scherrer's formula (Vidya and Chitra, 2017b).

\section{Experimental design}

Stock solutions of nanoparticles were prepared just before exposure by ultra-sonication at $100 \mathrm{kHz}$ for $30 \mathrm{~min}$ (except $\mathrm{SiO}_{2} \mathrm{NPs}$, only $10 \mathrm{~min}$ ) using double distilled water for dissolution. The median lethal concentrations $\left(\mathrm{LC}_{50}-96 \mathrm{~h}\right)$ of nanoparticles by using probit analysis were $\mathrm{Al}_{2} \mathrm{O}_{3} \mathrm{NPs}-40$ $\mathrm{mg} / \mathrm{L}, \quad \mathrm{SiO}_{2} \mathrm{NPs}-120 \mathrm{mg} / \mathrm{L}$ and $\mathrm{TiO}_{2} \mathrm{NPs}-164 \mathrm{mg} / \mathrm{L}$, respectively. ${ }^{[21]}$ One-tenth of $\mathrm{LC}_{50}-96 \mathrm{~h}$ of nanoparticles, namely $4 \mathrm{mg} / \mathrm{L}, 12 \mathrm{mg} / \mathrm{L}$ and $16.4 \mathrm{mg} / \mathrm{L}$ for $\mathrm{Al}_{2} \mathrm{O}_{3}, \mathrm{SiO}_{2}$, and $\mathrm{TiO}_{2}$, respectively, were selected for the present study. Conversely, no $50 \%$ mortality was observed for $\mathrm{Fe}_{3} \mathrm{O}_{4} \mathrm{NPs}$ when exposed up to $150 \mathrm{mg} / \mathrm{L}$, however, when above this concentration, aggregation and agglomeration was observed. Therefore, one-tenth of $150 \mathrm{mg} / \mathrm{L}$, i.e. $15 \mathrm{mg} / \mathrm{L}$, was chosen as a test concentration for $\mathrm{Fe}_{3} \mathrm{O}_{4} \mathrm{NPs}$. All the nanoparticles selected at the mentioned concentrations were exposed for short-term (24, 72 and $96 \mathrm{~h}$ ) and longterm ( 15,30 and 60 days) durations maintaining the control group. At the end of every exposure period, fishes were caught with least disturbance using small dip nets in order to avoid stress. Blood was collected by cardiac puncture and used for performing the genotoxic assays.

\section{Micronucleus test}

Micronucleus test was performed according to Heddle (1973) and Schimd (1975). In a clean glass slide, a drop of fish blood and a drop of foetal bovine serum (FBS) was mixed thoroughly and smeared. Slide was then air-dried and fixed in absolute methanol for $10 \mathrm{~min}$, followed by staining using 5\% Giemsa for $10 \mathrm{~min}$ and allowed to dry. A total of 1000 erythrocytes from both control and treatment groups were scored for nuclear and cellular anomalies according to Carrasco et al. (1990) with slight modifications, and observed under microscope at 100x magnification.

\section{Comet assay}

Alkaline comet assay or single cell gel electrophoresis (SCGE) were performed according to the method of Singh et al. (1988) with slight modifications. Slides were prepared by pre-coating $1 \%$ normal melting point agarose (NMA) in double distilled water and stored at $4^{\circ} \mathrm{C}$. To form the second supportive layer, $0.5 \%$ low melting point agarose (LMA) was spread uniformly over the first layer of agarose using a coverslip. The slide was further kept at $4^{\circ} \mathrm{C}$ for 5 min to allow complete polymerization of the agarose. After the coverslips were removed, $30 \mu \mathrm{l}$ of blood sample was gently mixed with $50 \mu \mathrm{l}$ of $1 \%$ LMA agarose, pipetted on the supportive layer of $1 \%$ NMA agarose and again covered with a coverslip. After keeping coverslips for 5 min on ice, they were removed and the slides were placed into freshly made cold lysis buffer (2.5 M NaCl, $100 \mathrm{mM} \mathrm{Na}{ }_{2}$ EDTA, $10 \mathrm{mM}$ Tris, $1.5 \%$ Triton $\mathrm{X}-100$ and $1 \%$ SDS, pH 10 along with 10\% dimethyl sulfoxide) for $2 \mathrm{~h}$. To allow DNA unwinding, slides were then placed in electrophoresis chamber containing cold alkaline electrophoresis buffer $(300 \mathrm{mM} \mathrm{NaOH}$ and $1 \mathrm{mM} \mathrm{Na}$ EDTA, pH13) for $20 \mathrm{~min}$. Electrophoresis was performed by applying electric current at $0.8 \mathrm{~V} /$ $\mathrm{cm}$ at $4^{\circ} \mathrm{C}$ for $20 \mathrm{~min}$. After electrophoresis, slides were washed thrice for $15 \mathrm{~min}$ in freshly prepared neutralization buffer (0.4 M Tris, $\mathrm{pH}$ 7.5). Staining was done using $50 \mu \mathrm{l}$ ethidium bromide (EtBr-10 $\mu \mathrm{g} / \mathrm{ml})$. The stained slides were observed using fluorescence inverted microscope (Olympus CKX41), using Green filter (Excitation filter BP480-550C) at $40 \mathrm{x}$ magnifications, and the images were captured using C-mount camera (Optika pro5 CCD camera). The microscopic images of comets were scored using software Comet Imager V 2.2.1. (MetaSystems, GmbH, Germany). Images of 50 cells were analysed randomly from each group and the tail length and \%tail DNA are the parameters chosen to evaluate DNA damage. According to the percent of DNA in the comet tail, DNA damages are divided into 5 grades ranging from 0-4 (Collins et al., 2004). Grade 0 represents no damage (\%tail DNA $<5 \%$ ), grade 1 signifies slight damage (\%tail DNA 5-20\%), grade 2 denotes medium damage (\%tail DNA 20-40\%), grade 3 indicates high damage (\%tail DNA 40-95\%) and grade 4 specifies severe damage (\%tail DNA >95\%). Then the overall score is calculated using the formula:

Total score $=(\%$ of cells in grade $0 \times 0)+(\%$ of cells in grade $1 \times 1)+(\%$ of cells in grade $2 \times 2)+(\%$ of cells in grade $3 \times$ $3)+(\%$ of cells in grade $4 \times 4)$ 


\section{RESULTS}

\section{Micronucleus test}

Exposure of selected nanoparticles showed nuclear and cytoplasmic abnormalities in all treatment groups. Frequencies ofmicronuclei formation and otherabnormalities such as binucleated cells, nuclear bud, irregularly shaped nucleus, sticky cells and vacoulated cytoplasm increased in time-dependent manner when compared to the control group (Table 1; Fig. 1).

\section{Comet assay}

The results obtained by the comet assay after exposure to nanoparticles on the erythrocytes of Oreochromis mossambicus are shown in Table 2. Comet length and percent tail DNA are the two parameters used to measure the DNA damage. Exposure to all nanoparticles showed a significant $(\mathrm{P}<0.05)$ increase in the tail length and percent tail DNA in time-dependant manner (Table 2). The total score of DNA damage grades of all nanoparticles are represented in Table 3 and Fig. 2.

Table 1. Effect of selected nanoparticles on micronuclei formation and other nuclear and cytoplasmic abnormalities in erythrocytes of Oreochromis mossambicus

\begin{tabular}{|c|c|c|c|c|c|c|c|}
\hline \multicolumn{2}{|c|}{ Treatment groups } & \multirow{2}{*}{$\frac{\text { Micronucleus }}{2 \pm 1.41}$} & \multirow{2}{*}{$\frac{\text { Binucleated }}{5 \pm 0.01}$} & \multirow{2}{*}{$\frac{\text { Nuclearbud }}{2 \pm 0.01}$} & \multirow{2}{*}{$\begin{array}{l}\text { Irregular nucleus } \\
0.5 \pm 0.7\end{array}$} & \multirow{2}{*}{$\begin{array}{l}\text { Sticky cells } \\
1 \pm 0.01\end{array}$} & \multirow{2}{*}{$\begin{array}{l}\text { Vacuolated cytoplasm } \\
1.5 \pm 0.7\end{array}$} \\
\hline \multirow{7}{*}{ 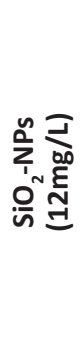 } & Control & & & & & & \\
\hline & $24 \mathrm{~h}$ & $11 \pm 1.05^{*}$ & $5 \pm 0.01$ & $2 \pm 1.41$ & $3 \pm 0.02 *$ & $1.5 \pm 0.7$ & $12 \pm 1.41^{*}$ \\
\hline & $72 \mathrm{~h}$ & $13 \pm 0.02^{*}$ & $8 \pm 1.82$ & $4 \pm 0.05$ & $6.5 \pm 1.12 *$ & $3 \pm 0.01 *$ & $15 \pm 0.001^{*}$ \\
\hline & $96 \mathrm{~h}$ & $14 \pm 2.82 *$ & $9 \pm 1.41 *$ & $4 \pm 1.05$ & $10 \pm 0.01 *$ & $4.5 \pm 0.71 *$ & $20.5 \pm 0.67^{*}$ \\
\hline & 15 days & $22 \pm 0.07^{*}$ & $13 \pm 1.34^{*}$ & $7.5 \pm 0.67^{*}$ & $11 \pm 0.75^{*}$ & $6 \pm 0.02 *$ & $25 \pm 0.43^{*}$ \\
\hline & 30 days & $38 \pm 1.42^{*}$ & $20.5 \pm 0.66^{*}$ & $8 \pm 0.001^{*}$ & $11 \pm 0.01 *$ & $7 \pm 0.45^{*}$ & $40.5 \pm 0.71^{*}$ \\
\hline & 60 days & $59 \pm 0.02 *$ & $20 \pm 0.03^{*}$ & $17.5 \pm 0.17^{*}$ & $17.5 \pm 0.16^{*}$ & $8 \pm 1.42 *$ & $54.5 \pm 3.53^{*}$ \\
\hline \multirow{7}{*}{ 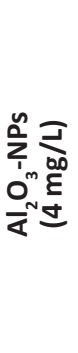 } & Control & $2 \pm 1.41$ & $5 \pm 0.01$ & $2 \pm 0.01$ & $0.5 \pm 0.7$ & $1 \pm 0.01$ & $1.5 \pm 0.7$ \\
\hline & $24 \mathrm{~h}$ & $4 \pm 0.03^{*}$ & $4.5 \pm 0.16$ & $4 \pm 0.01$ & $6.5 \pm 0.11^{*}$ & $3.5 \pm 1.06^{*}$ & $4 \pm 0.01^{*}$ \\
\hline & $72 \mathrm{~h}$ & $6 \pm 1.14^{*}$ & $4 \pm 1.12$ & $6 \pm 1.01^{*}$ & $9.5 \pm 0.21 *$ & $5.5 \pm 0.45^{*}$ & $3 \pm 0.1 *$ \\
\hline & $96 \mathrm{~h}$ & $8 \pm 0.02 *$ & $5 \pm 0.34$ & $8 \pm 0.41^{*}$ & $15 \pm 0.03^{*}$ & $8 \pm 0.13^{*}$ & $7 \pm 0.01 *$ \\
\hline & 15 days & $15.5 \pm 0.70^{*}$ & $8 \pm 0.02$ & $14 \pm 1.34^{*}$ & $16.5 \pm 0.7^{*}$ & $10 \pm 0.05^{*}$ & $14 \pm 2.82^{*}$ \\
\hline & 30 days & $29.5 \pm 1.13^{*}$ & $11 \pm 0.21^{*}$ & $20 \pm 0.04^{*}$ & $43 \pm 0.56^{*}$ & $19 \pm 1.44^{*}$ & $16 \pm 1.21 *$ \\
\hline & 60 days & $52 \pm 2.82^{*}$ & $15 \pm 1.65^{*}$ & $23.5 \pm 0.63^{*}$ & $106 \pm 1.41^{*}$ & $20.5 \pm 0.6^{*}$ & $24.5 \pm 0.77^{*}$ \\
\hline \multirow{7}{*}{ 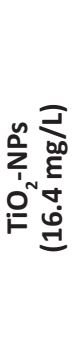 } & Control & $2 \pm 1.41$ & $5 \pm 0.01$ & $2 \pm 0.01$ & $0.5 \pm 0.7$ & $1 \pm 0.01$ & $1.5 \pm 0.7$ \\
\hline & $24 \mathrm{~h}$ & $3.5 \pm 0.67^{*}$ & $5 \pm 0.03$ & $6.5 \pm 0.12^{*}$ & $9 \pm 0.24 *$ & $3 \pm 0.01 *$ & $7 \pm 0.18^{*}$ \\
\hline & $72 \mathrm{~h}$ & $6 \pm 0.04 *$ & $4.5 \pm 0.07$ & $7 \pm 0.02 *$ & $11.5 \pm 0.18^{*}$ & $3.5 \pm 0.11^{*}$ & $9 \pm 0.001 *$ \\
\hline & $96 \mathrm{~h}$ & $8 \pm 1.41^{*}$ & $6 \pm 1.21$ & $10 \pm 1.24 *$ & $18 \pm 1.12^{*}$ & $6 \pm 0.21 *$ & $12 \pm 0.42^{*}$ \\
\hline & 15 days & $17.5 \pm 1.71 *$ & $11 \pm 0.77^{*}$ & $17.5 \pm 1.76^{*}$ & $21.5 \pm 1.32 *$ & $7 \pm 0.42 *$ & $21 \pm 0.01^{*}$ \\
\hline & 30 days & $30.5 \pm 0.81^{*}$ & $17 \pm 0.76^{*}$ & $28 \pm 0.01^{*}$ & $28.5 \pm 0.67^{*}$ & $12 \pm 0.05^{*}$ & $27.5 \pm 2.78^{*}$ \\
\hline & 60 days & $55 \pm 0.35^{*}$ & $23.5 \pm 0.65^{*}$ & $32 \pm 0.27^{*}$ & $38 \pm 1.25^{*}$ & $16 \pm 1.84^{*}$ & $32.5 \pm 0.81^{*}$ \\
\hline \multirow{7}{*}{ 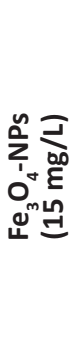 } & Control & $2 \pm 1.41$ & $5 \pm 0.01$ & $2 \pm 0.01$ & $0.5 \pm 0.7$ & $1 \pm 0.01$ & $1.5 \pm 0.7$ \\
\hline & $24 \mathrm{~h}$ & $5.5 \pm 0.78^{*}$ & $5 \pm 0.04$ & $8.5 \pm 0.71^{*}$ & $7.5 \pm 0.66^{*}$ & $3 \pm 0.01 *$ & $8.5 \pm 0.67^{*}$ \\
\hline & $72 \mathrm{~h}$ & $8 \pm 0.05^{*}$ & $4.5 \pm 0.65$ & $11 \pm 0.03^{*}$ & $11 \pm 0.07^{*}$ & $4 \pm 0.32 *$ & $11 \pm 0.21^{*}$ \\
\hline & $96 \mathrm{~h}$ & $13 \pm 0.65^{*}$ & $7.5 \pm 0.55$ & $12 \pm 0.56^{*}$ & $14 \pm 0.35^{*}$ & $6 \pm 0.07 *$ & $14.5 \pm 0.78^{*}$ \\
\hline & 15 days & $19 \pm 2.82^{*}$ & $9 \pm 1.41^{*}$ & $17.5 \pm 0.71^{*}$ & $17.5 \pm 0.67^{*}$ & $8 \pm 0.62^{*}$ & $19 \pm 0.43^{*}$ \\
\hline & 30 days & $32.5 \pm 0.77^{*}$ & $12 \pm 0.07^{*}$ & $27 \pm 0.03^{*}$ & $26 \pm 0.04^{*}$ & $11 \pm 1.12^{*}$ & $31 \pm 1.21^{*}$ \\
\hline & 60 days & $68.5 \pm 0.82 *$ & $19 \pm 2.84^{*}$ & $38 \pm 1.71^{*}$ & $34.5 \pm 1.06 *$ & $13.5 \pm 1.2^{*}$ & $36 \pm 1.25^{*}$ \\
\hline
\end{tabular}

Mean $\pm \mathrm{SD}$; * denotes significance at $\mathrm{P}<0.05$ against the control group 


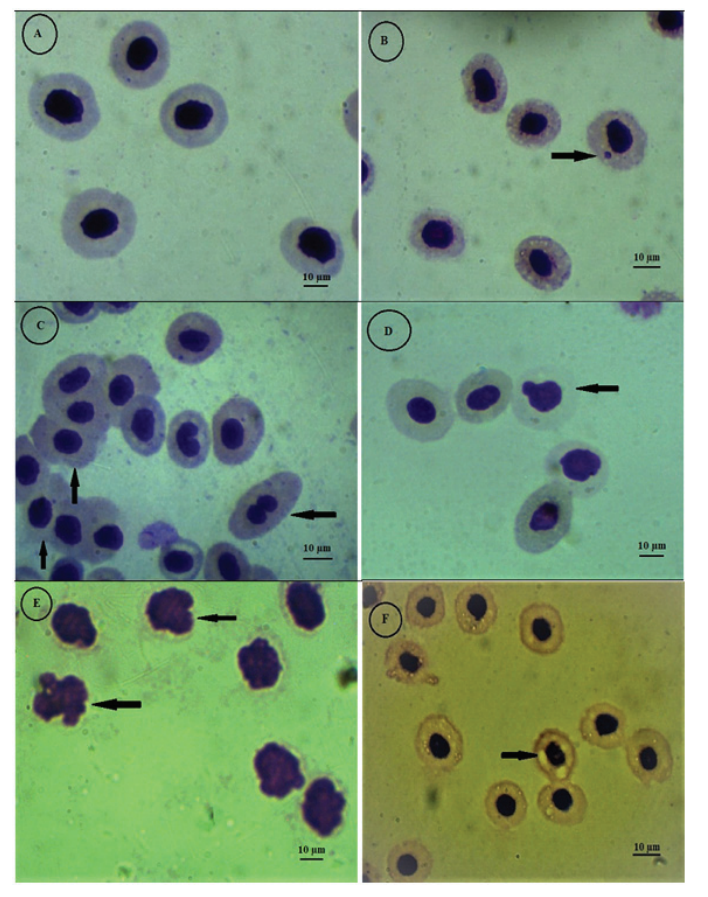

Fig 1. Fish erythrocytes exposed to nanoparticles showing $A$ - normal erythrocytes (control); B - erythrocytes with micronucleus $(\rightarrow)$; C - binucleated $(\leftarrow)$ and sticky cells ( $\uparrow)$; D - nuclear bud $(\leftarrow)$; E - irregular nucleus $(\leftarrow)$; F - cytoplasmic vacuolization $(\rightarrow)$
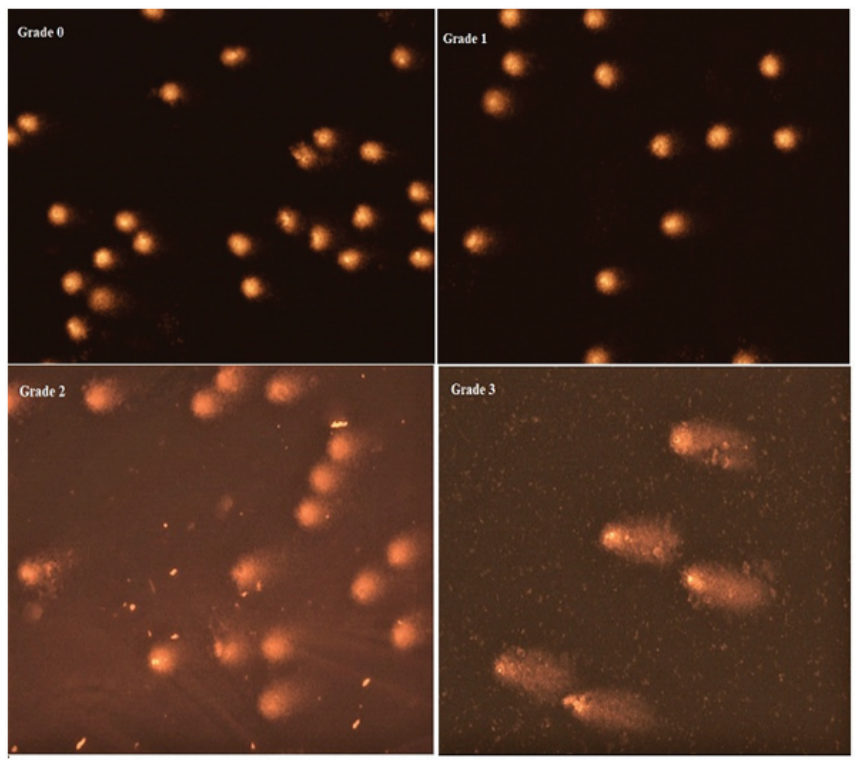

Table 2. Variation in tail length and tail DNA (\%) after nanoparticle exposure in Oreochromis mossambicus

\begin{tabular}{|c|c|c|c|}
\hline \multicolumn{2}{|c|}{ Treatment groups } & \multirow{2}{*}{$\begin{array}{l}\text { Tail length } \\
9.71 \pm 3.74\end{array}$} & \multirow{2}{*}{$\begin{array}{l}\text { Tail DNA (\%) } \\
4.60 \pm 1.96\end{array}$} \\
\hline \multirow{7}{*}{ 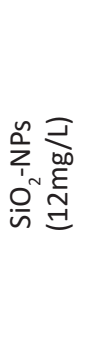 } & Control & & \\
\hline & $24 \mathrm{~h}$ & $10.42 \pm 3.04$ & $9.77 \pm 2.38$ \\
\hline & $72 \mathrm{~h}$ & $15.59 \pm 2.93^{*}$ & $11.17 \pm 2.83^{*}$ \\
\hline & $96 h$ & $21.63 \pm 3.64 *$ & $15.59 \pm 5.74^{*}$ \\
\hline & 15 days & $28.05 \pm 3.55^{*}$ & $17.86 \pm 3.58^{*}$ \\
\hline & 30 days & $33.37 \pm 2.68^{*}$ & $20.06 \pm 4.49 *$ \\
\hline & 60 days & $41.71 \pm 4.07^{*}$ & $32.93 \pm 8.49 *$ \\
\hline \multirow{7}{*}{ 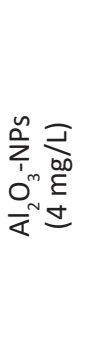 } & Control & $9.71 \pm 3.74$ & $4.60 \pm 1.96$ \\
\hline & $24 \mathrm{~h}$ & $18.78 \pm 3.72^{*}$ & $13.05 \pm 5.00 *$ \\
\hline & $72 \mathrm{~h}$ & $24.12 \pm 6.30^{*}$ & $22.26 \pm 4.29 *$ \\
\hline & $96 \mathrm{~h}$ & $33.32 \pm 5.26^{*}$ & $27.96 \pm 4.18^{*}$ \\
\hline & 15 days & $35.85 \pm 5.19 *$ & $31.72 \pm 3.54^{*}$ \\
\hline & 30 days & $44.94 \pm 6.33^{*}$ & $35.84 \pm 3.76^{*}$ \\
\hline & 60 days & $86.69 \pm 4.43^{*}$ & $40.20 \pm 4.66^{*}$ \\
\hline \multirow{7}{*}{ 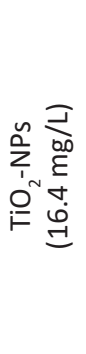 } & Control & $9.71 \pm 3.74$ & $4.60 \pm 1.96$ \\
\hline & $24 \mathrm{~h}$ & $17.39 \pm 3.85^{*}$ & $10.07 \pm 3.15^{*}$ \\
\hline & $72 \mathrm{~h}$ & $25.78 \pm 3.35^{*}$ & $13.58 \pm 3.59 *$ \\
\hline & $96 h$ & $31.88 \pm 3.94^{*}$ & $18.95 \pm 5.88^{*}$ \\
\hline & 15 days & $43.52 \pm 3.43^{*}$ & $26.26 \pm 6.68^{*}$ \\
\hline & 30 days & $53.87 \pm 4.02 *$ & $32.39 \pm 4.45^{*}$ \\
\hline & 60 days & $78.82 \pm 4.93^{*}$ & $36.62 \pm 7.52 *$ \\
\hline \multirow{7}{*}{ 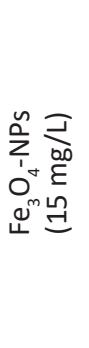 } & Control & $9.71 \pm 3.74$ & $4.60 \pm 1.96$ \\
\hline & $24 \mathrm{~h}$ & $9.11 \pm 1.97$ & $13.06 \pm 5.89 *$ \\
\hline & $72 \mathrm{~h}$ & $18.95 \pm 3.64^{*}$ & $19.00 \pm 6.40^{*}$ \\
\hline & $96 h$ & $29.17 \pm 4.58^{*}$ & $24.76 \pm 7.41^{*}$ \\
\hline & 15 days & $40.14 \pm 5.98^{*}$ & $28.25 \pm 6.86^{*}$ \\
\hline & 30 days & $45.22 \pm 5.69 *$ & $32.14 \pm 6.57^{*}$ \\
\hline & 60 days & $82.91 \pm 3.81 *$ & $38.81 \pm 5.72^{*}$ \\
\hline
\end{tabular}

Mean $\pm \mathrm{SD}$; ${ }^{*}$ denotes significance at $\mathrm{P}<0.05$ against the control group

Fig 2. Comet morphology showing different grades of DNA damage after nanoparticle exposure 
Table 3. DNA damage grades in the fish exposed to selected nanoparticles

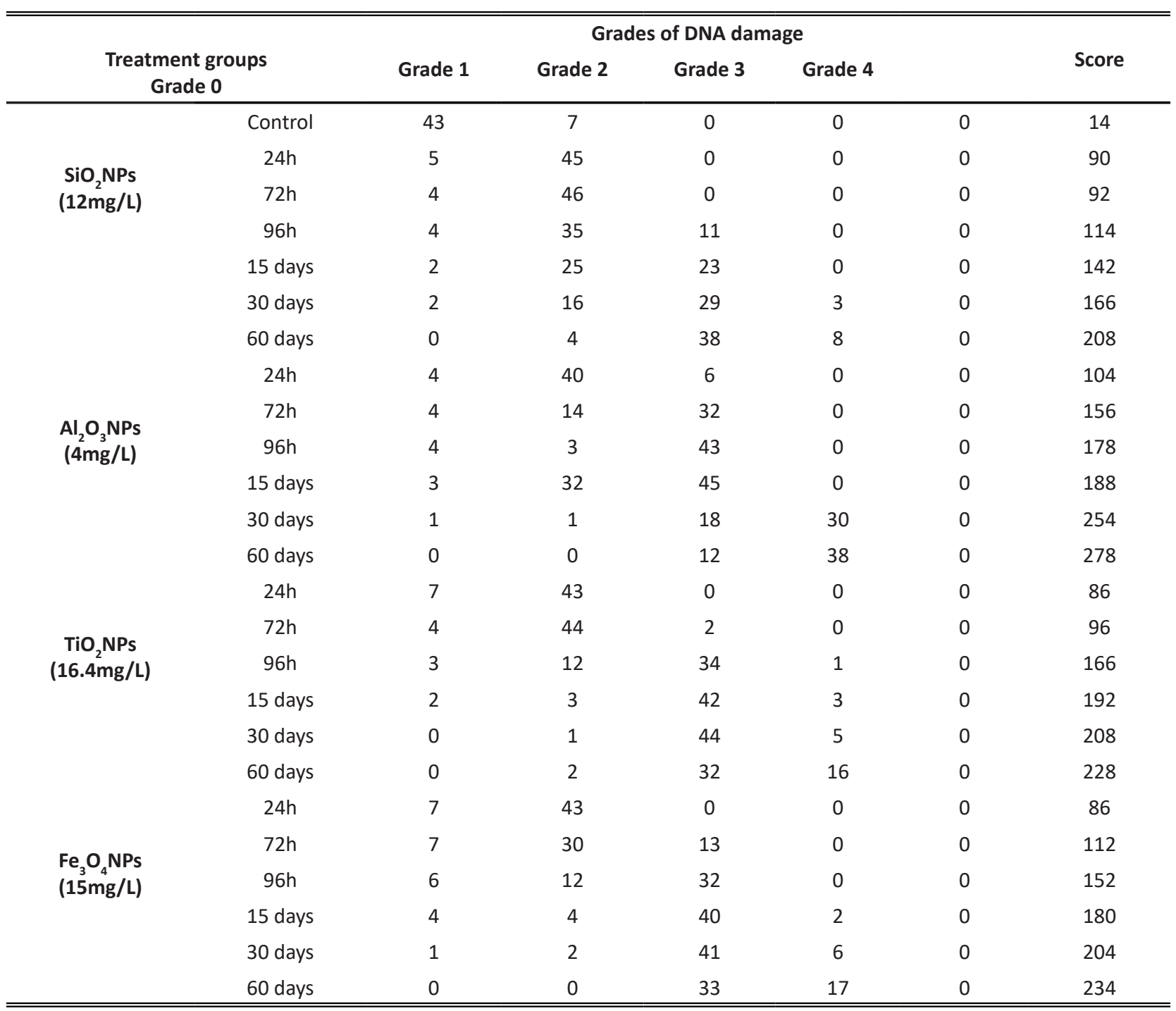

\section{DISCUSSION}

There is an increasing concern on the steady rise in the use and manufacture of nanoparticles throughout the world. Therefore, risk assessment of the nanoparticles is an inevitable issue in ecogenotoxicological research. Genotoxic effects of nanoparticles need to be carefully evaluated as there is correlation to various diseases including cancer or risk of inherited genetic damage. There is literature suggesting both positive and negative genotoxic effects of nanoparticles. The mechanisms behind the genotoxicity of nanoparticles have been classified as primary or secondary genotoxicity (Schins and Knaapen, 2007). Primary genotoxicity refers to the induction of genetic damage as a result of the physicochemical properties of nanoparticles, whereas secondary genotoxicity refers to the genetic damage caused as a result of reactive oxygen species generation during particle-elicited inflammation (Schins and Knaapen, 2007).
Size, concentration, stability and duration of exposure to nanoparticles are some of the primary properties that elicit direct genotoxic effects on the exposed organisms. Particles of size less than $30 \mathrm{~nm}$ have been shown to enter the cell nucleus, either by passing through the nuclear pore or by direct interaction with DNA during mitosis, thereby represent nano-specific mechanism of toxicity (Nabiev et al., 2007). However, the other mechanism leading to genotoxicity of nanoparticles is by the induction of oxidative stress. Our previous findings have reported that nanoparticles induced irreversible alterations on the antioxidant defence system in Oreochromis mossambicus (Vidya and Chitra, 2018a, b). Thus the main purpose of the present investigation is testing the hypothesis that the selected metal oxide nanoparticles exert the genotoxicity in the freshwater fish Oreochromis mossambicus, based on primary or secondary mechanism. Scientific literature has reported several methods for 
genotoxicity testing of nanoparticles. In particular, micronucleus assay, comet assay, chromosomal aberrations, bacterial and mammalian mutagenicity tests and cell transformation assays are the most commonly used assays for assessing genetic damage induced by nanoparticles in vivo and in vitro. The present study focussed on micronucleus assay and single-cell gel electrophoresis or comet assay as the test battery to assess genotoxicity of metal oxide nanoparticles. Fish erythrocyte micronucleus test is a widely accepted simple, reliable and successful cytogenetic technique, hence preferred as a biomarker for genotoxicity assessment in aquatic ecosystem. Micronucleus analysis has been performed in different cell types like kidney, gill, fin, hepatocytes, etc., but isolation procedures of different cell types remain complex and confer obscure results (Al-Sabti and Metcalfe, 1995). Micronucleus test in fish erythrocyte is considered as a perfect, reliable and easy procedure that detects genotoxicity in aquatic organisms. Micronucleus mainly originates at the end of mitotic telophase as a result of spindle defects during the segregation process in anaphase. Thus misrepair of DNA double strand breaks occur leading to the formation of acentric chromosomes or chromatid fragments, or whole chromosomes that fail to be incorporated in the daughter nuclei (Fenech et al., 2011). Micronucleus containing chromosome or chromatid fragments are enclosed by a nuclear membrane showing similar morphology to nuclei after conventional nuclear staining. However, the size of micronucleus is relatively small, which is between $1 / 18$ and $1 / 3$ of that of the main nucleus. Micronucleus assay helps to detect both chromosome breakage, i.e. clastogenicity, induced by reactive oxygen species, as well as aneuploidogenic effects that can be due to physical disturbance of spindle or mitotic apparatus (Pfuhler et al., 2013). In the present study, exposure to the selected nanoparticles showed induction of micronuclei, where the frequency of micronuclei increased in a timedependant manner. Besides micronuclei formation, other nuclear abnormalities such as binucleated, nuclear bud, irregular nuclei and sticky and vacuolated cells were also observed after exposure to all nanoparticles.

The formation of morphological nuclear alterations was first described in fish erythrocytes. Binucleated cells are produced as a result of improper cell division thereby leading to the failure of mitotic spindle formation whereas DNA amplification or broken DNA bridge are the mechanism behind nuclear bud formation (de Campos Ventura et al., 2008). The formation of nuclear abnormalities would represent the way to eliminate toxic chemicals that amplify genetic material from the cell nucleus (Carrasco et al., 1990). The cytoplasmic anomalies like sticky cells and vacuolated cytoplasm were also evident in all treatment groups. Vacuolated cytoplasm was prominent in erythrocytes of fishes exposed to nanoparticles and this might be due to the unequal distribution of haemoglobin (Ateeq et al., 2002). The induction of genotoxic damage as evident by the formation of micronucleus and other nuclear abnormalities reveal the genotoxic effects of nanoparticles in Oreochromis mossambicus. The result coincides with another study demonstrating increase in the frequency of micronucleus in the fish Catla catla when irradiated with gamma radiation (Anbumani and Mohankumar, 2002).

Comet assay is a relatively simple, rapid and sensitive method for detecting DNA damage such as single stranded breaks, alkali labile sites, protein-DNA and DNA-DNA cross-links in single cell suspensions (Collins, 2004). Comet assay has been widely used to determine oxidative DNA damage, to screen novel drugs and cosmetics, in chemo-preventive studies by assessing tumour radio-sensitivity and chemo-sensitivity, thereby it plays a major role in cancer therapy (Collins et al., 1997). Exposure to toxicants allow break in DNA followed by relaxing supercoiling of DNA so the negatively charged fragments of DNA are enabled to move through an agarose gel in response to an electric field. The extent of DNA migration depends directly on the DNA damage present in the cells giving the image as comet-like appearance (Tice et al., 2000). The widely used comet parameters to evaluate DNA damage are tail length, \% tail DNA, tail moment, olive moment, etc. The percentage of DNA in the tail is measured as the ratio between the total intensity of the tail and the total intensity of the comet, whereas tail extent moment is the product of the tail length and the percentage of DNA in the tail (Collins et al., 2008). Olive tail moment is another parameter of comet assay calculated as the product of two factors such as the percentage of DNA in the tail and the distance between the centroids of the head and tail. Olive tail moment is thus useful in describing heterogeneity within the cell population (Olive et al., 1990). Tail length and \%tail DNA are the parameters used in the present study to evaluate genetic damage due to nanoparticle exposure. The results suggest that exposure to all nanoparticles significantly increased tail length as well as percent tail DNA in a time-dependant manner. Scoring of comet is performed in the present study according to the standard procedure where the degree of damage was classified into five grades as Grade 0 to 4 (Collins, 2004). Grade 0 represents no tail and based on the percent tail DNA the grade increases, where the selected nanoparticles exposure did not show high intensity of DNA damage, therefore grade 4 was not observed in all treatment groups. Genetic damages measured by comet assay showed significant increase in tail length and \%tail DNA, which represents genotoxic damage in the erythrocytes of Oreochromis mossambicus when exposed to nanoparticles. Induction of genetic damage was observed equally in all nanoparticles tested irrespective of the particle size. However, depending on the mechanism of action of the tested nanoparticles, the genotoxicity test conducted by 
using micronucleus and comet bioassays lead to quandary conclusions that both nano-sized particles and the ability of nanoparticles to induce oxidative stress could be considered together for genotoxic effects.

\section{CONCLUSIONS}

In vivo genotoxicity tests conducted in different metal oxide nanoparticles revealed induction of genetic damage in Oreochromis mossambicus. Furthermore, both nanospecific as well as particle-elicited inflammation in the form of generation of reactive oxygen species plays equal role in the induction of genotoxicity of the selected nanoparticles in the exposed fish.

\section{ACKNOWLEDGEMENT}

Authors gratefully acknowledge UGC-SAP, Government of India for the financial assistance.

\section{SAŽETAK}

\section{PROCJENA GENETSKIH OŠTEĆENJA KOD Oreochromis mossambicus IZLOŽENOJ ODABRANIM NANOČESTICAMAKORISTEĆI MIKRONUKLEUS I KOMET TEST}

Cilj istraživanja je proširiti znanje o štetnim učincima nanočestica procjenom genotoksičnosti, kao ocjenom rizika za okoliš, kod mozambičke tilapije Oreochromis mossambicus. Ribe su bile izložene subletalnim koncentracijama odabranih nanočestica kao što su silicijev dioksid $\left(\mathrm{SiO}_{2} \mathrm{NPs}-12 \mathrm{mg} / \mathrm{L}\right)$, aluminij oksid $\left(\mathrm{Al}_{2} \mathrm{O}_{3} \mathrm{NPs}-4\right.$ $\mathrm{mg} / \mathrm{L})$, titanijev dioksid $\left(\mathrm{TiO}_{2} \mathrm{NPs}-16.4 \mathrm{mg} / \mathrm{L}\right)$ i željezni oksid $\left(\mathrm{Fe}_{3} \mathrm{O}_{4} \mathrm{NPs}-15 \mathrm{mg} / \mathrm{L}\right)$ u kratkotrajnim (24, $72 \mathrm{i}$ 96 h) i dugotrajnim vremenskim rasponima (15, 30 i 60 dana). Genetska oštećenja, kao što su citoplazmatska, nuklearna i oštećenja DNK, izmjerena su u eritrocitima riba korištenjem standardnih testova genotoksičnosti mikronukleus i komet test. Učestalost mikronukleusa, zajedno s nuklearnim i citoplazmatskim abnormalnostima, zabilježena je i uspoređena s kontrolnom skupinom. U ovisnosti o vremenu, kod svih izloženih skupina, pri usporedbi s kontrolom, utvrđen je značajno povišen intenzitet mikronukleusa $(p<0,05)$ zajedno s ostalim nuklearnim i citoplazmatskim anomalijama, što ukazuje na kromosomske oštećenja kao posljedica kontakta s nanočesticama. Također, ovisno o vremenu, duljina i postotak repa DNK unutar kometa značajno se povećala $(p<0,05)$ nakon izlaganja svim nanočesticama, što ukazuje povećanje oštećenja DNK. U konačnici, koristeći mikronukleus i komet test, očito je da odabrane nanočestice u subletalnim koncentracijama izazivaju genetska oštećenja kod Oreochromis mossambicus.

Ključne riječi: Oreochromis mossambicus, nanočestice, eritrociti, genotoksičnost, mikronuleus test, komet test

\section{REFERENCES}

Al-Sabti, K., Metcalfe, C. D. (1995): Fish micronuclei for assessing genotoxicity in water. Mutation Research. 343, 2-3, 121-135.

Anbumani, S., Mohankumar, M.N. (2012): Gamma radiation induced micronuclei and erythrocyte cellular abnormalities in the fish Catla catla. Aquatic Toxicology. 122-123, 125-132.

Ansari, M.A., Khan, H.M., Khan, A.A., Cameotra, S.S., Saquib, Q., Musarrat, J. (2014): Interaction of $\mathrm{Al}_{2} \mathrm{O}_{3}$ nanoparticles with Escherichia coli and their cell envelope biomolecules. Journal of Applied Microbiology. 116, 4, 772-783.

APHA. Standard methods for the examination of water and waste water, 20 ${ }^{\text {th }}$ Edition, Washington, DC. 1998.

Ateeq, M.B., Farah, M.A., Ali, N., Ahmad, W. (2002): Induction of micronuclei and erythrocyte alterations in the catfish Clarias batrachus by 2,4-dichlorophenoxyacetic acid and butachlor. Mutation Research. 518, 135-144.

Bickham, J.W., Sandhu, S., Hebert, P.D.N., Chikhi, L., Athwal, R. (2000): Effects of chemical contaminants on genetic diversity in natural populations: implications for biomonitoring and ecotoxicology. Mutation Research. 463, 1, 33-51.

Carrasco, K.R., Tilbury, K.L., Myers, M.S. (1990): Assessment of the piscine micronucleus test as in situ biological indicator of chemical contaminant effects. Canadian Journal of Fisheries and Aquatic Sciences. 47, 11, 21232136.

Chen, L., Yokel, R.A., Hennig, B., Toborek, M. (2008): Nano-alumina induces mitochondrial dysfunction and induces oxidative stress in HBMEC. Journal of Neuroimmune Pharmacology. 3, 4, 286-295.

Chen, X., Mao, S.S. (2007): Titanium dioxide nanomaterials: synthesis, properties, modifications, and applications. Chemical Reviews. 107, 7, 2891-2959.

Collins, A., Dusinska, M., Franklin, M., Somorovska, M., Petrovska, H., Duthie, S., Fillion, L., Panayiotidis, M., Raslova, K., Vaughan, N. (1997): Comet Assay in human biomonitoring studies: reliability, validation, and applications. Environmental and Molecular Mutagenesis. 30, 2, 139-146.

Collins, A.R. (2004): The comet assay for DNA damage and repair: principles, applications and limitations. Molecular Biotechnology. 26, 3, 249-261.

Collins, A.R., Oscoz, A.A., Brunborg, G., Gaivao, I., Giovannelli, L., Kruszewski, M., Smith, C.C., Štetina, R. (2008): 
The comet assay: topical issues. Mutagenesis 23, 3, 143-151.

Colvin, V.L. (2003): The potential environmental impact of engineered nanomaterials. Nature Biotechnology. 21, 10, 1166-1170.

de Campos Ventura, B., de Fransceschi de Angelis D., Marin-Morales, M.A. (2008): Mutagenic and genotoxic effects of the atrazine herbicide in Oreochromis niloticus (Perciformes, Cichlidae) detected by the micronuclei test and the comet assay. Pesticide Biochemistry and Physiology. 90, 1, 42-51.

De Flora, S., Bagnasco, S., Zanacchi, M. (1991): Genotoxic, carcinogenic, and teratogenic hazards in the marine environment, with special reference to the Mediterranean Sea. Mutation Research. 258, 3, 285-320.

De Jong, W. H., Borm, P. J. (2008): Drug delivery and nanoparticles: applications and hazards. International Journal of Nanomedicine. 3, 2, 133-149.

Federici, G., Shaw, B.J., Handy, R.D. (2007): Toxicity of titanium dioxide nanoparticles to rainbow trout (Oncorhynchus mykiss): Gill injury, oxidative stress, and other physiological effects. Aquatic Toxicology. 84, 4, 415-430.

Fenech, M., Kirsch-Volders, M., Natarajan, A.T., Surralles, J., Crott, J.W., Parry, J., Norppa, H., Eastmond, D.A., Tucker, J.D., Thomas, P. (2011): Molecular mechanisms of micronucleus, nucleoplasmic bridge and nuclear bud formation in mammalian and human cells. Mutagenesis 26, 1, 125-132.

Gupta, A.K., Gupta, M. (2005): Synthesis and surface engineering of iron oxide nanoparticles for biomedical applications. Biomaterials 26, 18, 3995-4021.

Heddle, J.A. (1973): A rapid in vivo test for chromosomal damage. Mutation Research. 18, 187-192.

Lam, P.K.S., Gray, J.S. (2003): The use of biomarkers in environmental monitoring programmes. Marine Pollution Bulletin. 46, 2, 182-186.

Li, Z., Barnes, J.C., Bosoy, A., Stoddart J.F., Zink, J.I. (2012): Mesoporous silica nanoparticles in biomedical applications. Chemical Society Reviews. 41, 7, 2590-2605.

Nabiev, I., Mitchell, S., Davies, A., Williams, Y., Kelleher, D., Moore, R., Gunko, Y.K., Byrne, S., Rakovish, Y.P., Donegan, J.G., Sukhanova, A., Conroy, J., Cottell, D., Gaponik, N., Rogach, A., Volkov, Y. (2007): Non-functionalized nanocrystals can exploit a cell's active transport machinery delivering them to specific nuclear and cytoplasmic compartments. Nano Letters. 7, 11, 34523461.

Nel, A., Xia, T., Mädler, L., Li, N. (2006): Toxic potential of materials at the nanolevel. Science 311, 5761, 622-627.

Oberdörster, G., Oberdörster, E., Oberdörster, G. (2005): Nanotoxicology: an emerging discipline evolving from studies of ultrafine particles. Environmental Health Per- spectives. $113,7,823-839$.

Olive, P.L., Banath, J.P., Durand, R.E. (1990): Heterogeneity in radiation induced DNA damage and repair in tumor and normal cells measured using the 'comet' assay. Radiation Research. 122, 1, 86-94.

Pfuhler, S., Elespuru, R., Aardema, M.J., Doak, S.H., Donner, E.M., Honma, M., Kirsch-Volders, M., Landsiedel, R., Manjanatha, M., Singer, T., Kim, J.H. (2013): Genotoxicity of nanomaterials: refining strategies and tests for hazard identification. Environmental and Molecular Mutagenesis. 54, 4, 229-239.

Sayes, C. M., Warheit, D. B. (2009): Characterization of nanomaterials for toxicity assessment. Wiley Interdisciplinary Reviews: Nanomedicine and Nanobiotechnology. 1, 6, 660-670.

Schins, R.P., Knaapen, A.M. (2007): Genotoxicity of poorly soluble particles. Inhalation Toxicology. 19, 1, 189-198.

Schmid, W. (1975): The micronucleus test. Mutation Research. 31, 1, 9-15.

Singh, N.P., McCoy, M.T., Tice, R.R., Schneider, E.L. (1988): A simple technique for quantitation of low levels of DNA damage in individual cells. Experimental Cell Research. 175, 1, 184-191.

Sumi, N., Chitra, K.C. (2017): Fullerene $\left(C_{60}\right)$ induced alteration in the brain antioxidant system of the cichlid fish, Pseudetroplus maculatus (Bloch, 1795). Journal of Global Biosciences. 6, (4), 4908-4917.

Tice, R.R., Agurell, E., Anderson, D., Burlinson, B., Hartmann, A., Kobayashi, H., Miyamae, Y., Rojas, E., Ryu, J., Sasaki, Y.F. (2000): Single cell gel/comet assay: guidelines for in vitro and in vivo genetic toxicology testing. Environmental and Molecular Mutagenesis. 35, 3, 206221.

Vidya, P.V., Chitra, K.C. (2017a): Induction of cytotoxicity by selected nanoparticles in Chinese Hamster Ovary-K1 cells. International Journal of Applied Science and Biotechnology. 5, 2, 203-207.

Vidya, P.V., Chitra, K.C. (2017b): Assessment of acute toxicity (LC ${ }_{50} 96 \mathrm{~h}$ ) of aluminium oxide, silicon dioxide and titanium dioxide nanoparticles on the freshwater fish, Oreochromis mossambicus (Peters, 1852). International Journal of Fisheries and Aquatic Studies. 5, 1, 327-332.

Vidya, P.V., Chitra, K.C. (2018a): Aluminium oxide nanoparticles induced irreversible alterations in the antioxidant defense system of the fish, Oreochromis mossambicus (Peters, 1852). European Journal of Biomedical and Pharmaceutical Sciences. 5, 2, 1162-1170.

Vidya, P.V., Chitra, K.C. (2018b): Persistent toxic effects of titanium dioxide nanoparticles after treatment withdrawal in the freshwater fish, Oreochromis mossambicus (Peters, 1852). World Journal of Pharmaceutical Life Sciences. 4, 2, 141-152. 
Vidya, P.V., George, A., Chitra, K.C. (2017): An in vitro study on the induction of micronuclei and other nuclear anomalies in peripheral blood lymphocyte culture by metal ox- ide nanoparticles. International Journal of Advanced Research in Biological Sciences. 4, 1, 1-8. 